\title{
HUBUNGAN ANTARA PARITAS DAN PARTUS LAMA DENGAN KEJADIAN ASFIKSIA NEONATORUM PADA BAYI BARU LAHIR
}

\author{
RELATIONSHIP BETWEEN PARITUS AND OLD PARTUSES WITH THE EVENT OF \\ NEONATORUM ASFIXIA IN NEW BORN BABY
}

Dwi Saputri Mayang Sari

Akademi Kebidanan Rangga Husada Prabumulih

Email: dwisaputri028@gmail.com

\begin{abstract}
ABSTRAK
Asfiksia Neonatorum adalah kegagalan untuk memulai dan melanjutkan pernafasan secara spontan dan teratur pada saat bayi baru lahir atau beberapa saat sesudah lahir. Bayi mungkin lahir dalam kondisi asfiksia atau mungkin dapat bernafas tetapi kemudian mengalami asfiksia beberapa saat setelah lahir . Tujuan dari penelitian ini adalah untuk mengetahui hubungan antara paritas dan partus lama dengan kejadian asfiksia neonatorum di rumah sakit umum daerah kota prabumulih tahun 2019. Penelitian ini menggunakan Survey Analitik dengan menggunakan pendekatan Cross Sectional. Populasi penelitian ini adalah bayi yang dilahirkan di rumah sakit umum daerah kota prabumulih tahun 2019 berjumlah 1763 orang. Jumlah sampel pada penelitian ini adalah 326 responden. Pada analisa univariat diketahui bahwa dari 326 responden didapatkan bahwa paritas ibu resiko tinggi sebanyak 168 responden (51,5\%) sedangkan paritas ibu resiko rendah sebanyak 158 responden $(48,5 \%)$ dan ibu yang didagnosa partus lama sebanyak 149 responden $(45,7 \%)$ sedangkan ibu yang tidak didiagnosa partus lama sebanyak 177 responden $(54,3 \%)$. Analisa Bivariat menunjukkan paritas mempunyai hubungan yang bermakna dengan kejadian asfiksia neonatorum ( $p$ value 0,000) dan partus lama mempunyai hubungan yang bermakna dengan kejadian asfiksia neonatorum ( $\mathrm{p}$ value 0,000). Dari penelitian ini bahwa ada hubungan antara paritas dan partus lama dengan kejadian asfiksia neonatorum.
\end{abstract}

Kata Kunci

: paritas, partus lama dan asfiksia neonatorum

\begin{abstract}
Asphyxia Neonatorum is a failure to start and continue breathing spontaneously and regularly when a new baby is born or some time after birth. Babies may be born in asphyxia or may be able to breathe but then experience asphyxia some time after birth. The purpose of this study was to determine the relationship between parity and old parturition with the incidence of asphyxia neonatorum in the pre-Sumatran city general hospital in 2019. This study uses an Analytical Survey using a Cross Sectional approach. The population of this research is the babies born in the prehumulih city general hospital in 2019 amounted to 1763 people. The number of samples in this study were 326 respondents. In the univariate analysis it was found that from 326 respondents it was found that parity of high risk mothers was 168 respondents (51.5\%) while parity of low risk mothers was 158 respondents (48.5\%) and mothers who were diagnosed with prolonged labor were 149 respondents (45.7 \%) while mothers who were not diagnosed with prolonged labor were 177 respondents (54.3\%). Bivariate analysis shows parity has a significant relationship with the incidence of asphyxia neonatorum ( $p$ value 0,000) and old parturition has a significant relationship with the incidence of asphyxia neonatorum ( $p$ value 0,000). The conclusion of this study is that there is a relationship between parity and old parturition with the incidence of asphyxia neonatorum.
\end{abstract}

Keywords : parity, old parturition and neonatal asphyxia 


\section{PENDAHULUAN}

Bayi Baru Lahir (BBL) adalah bayi yang lahir dengan umur kehamilan 37 minggu sampai 42 minggu, memiliki berat lahir 2500 gram sampai 4000 gram. Bayi baru lahir dapat dilahirkan melalui 2 cara, secara normal melalui vagina atau melalui operasi cesar. Bayi baru lahir harus mampu beradaptasi dengan lingkungan yang baru karena setelah plasentanya dipotong maka tidak ada lagi asupan makanan dari ibu selain itu kondisi bayi baru lahir masih rentan terhadap penyakit. Karena itulah bayi memerlukan perawatan yang insentif. Jagalah kebersihan bayi dan berikan nutrisi yang cukup kepada bayi melalui $\mathrm{ASI}^{4}$.

Asfiksia Neonatorum adalah kegagalan untuk memulai dan melanjutkan pernafasan secara spontan dan teratur pada saat bayi baru lahir atau beberapa saat sesudah lahir. Bayi mungkin lahir dalam kondisi asfiksia atau mungkin dapat bernafas tetapi kemudian mengalami asfiksia beberapa saat setelah lahir ${ }^{11}$.

Menurut World Health Organization (WHO) pada tahun 2018 sebanyak 7000 bayi baru lahir di dunia meninggal setiap harinya. Tiga perempat kematian neonatal terjadi pada minggu pertama dan $40 \%$ meninggal dalam 24 jam pertama. Kematian neonatal berkaitan erat dengan kualitas pelayanan persalinan dan penanganan bayi baru lahir yang kurang optimal segera setelah lahir dan beberapa hari pertama setelah lahir ${ }^{9}$.

Meski mengalami penurunan dari Tahun sebelumnya, jumlah tersebut masih terbilang cukup tinggi, jika dibandingkan target Sustainable Development Goals (SDG's) Tahun 2015, angka kematian bayi (AKB) 23 per 100.000 kelahiran hidup dan angka kematian balita (AKABA) 32 per 100.000 kelahiran hidup.
Adapun faktor penyebab dari asfiksia neonatorum yaitu faktor ibu seperti pre eklamsia dan eklamsi, perdarahan abnormal, partus lama atau macet, demam selama persalinan, infeksi berat, kehamilan lewat waktu, plasenta previa, anemia, faktor tali pusat yaitu lilitan tali pusat, tali pusat pendek, simpul tali pusat, prolapsus tali pusat dan faktor bayi yaitu bayi prematur, persalinan dengan tindakan, kelainan bawaan, air ketuban bercampur mekonium dan berat badan bayi ${ }^{10}$.

Menurut penelitian yang dilakukan oleh Elvina 2016 menyatakan bahwa ibu yang baru pertama kali melahirkan cenderung mengalami kesulitan dibandingkan dengan ibu yang sudah pernah melahirkan, hal ini disebabkan karena ibu dengan paritas primipara akan mengalami kesulitan saat persalinan akibat otot-otot masih kaku dan belum elastis sehingga akan mempengaruhi lamanya persalinan sehingga menyebabkan bayi mengalami asfiksia, sedangkan pada ibu dengan paritas multipara mengalami kelemahan ataupun kurangnya kekuatan otot rahim sehingga dapat memperpanjang proses persalinan. Maka dari itu partus lama sangat berpengaruh pada kejadian asfiksia neonatorum.

Menurut penelitian yang dilakukan oleh Ayu Mustika Handayani (2018) di RSU Kota Jambi didapatkan bahwa $p$ value $=$ $0,000<0,05$ maka H0 ditolak dan $\mathrm{Ha}$ diterima artinya ada hubungan antara partus lama dengan kejadian asfiksia neonatorum ${ }^{1}$.

Penelitian ini sesuai dengan teori bahwa dalam proses persalinan terjadi kontraksi uterus kala II saat kontraksi berlangsung secara konsisten 90 detik, jumlah kontaksi adalah 3-4 kali tiap menit atau terjadi setiap 2-3 menit sekali, sehingga aliran darah ke janin dapat berkurang atau berhenti. Stimulasi kontraksi uterus yang berlebihan atau kurang sempurna dan 
lamanya persalinan kala II dengan teknik mengejan yang aktif berlangsung lebih dari 1 jam pada ibu primipara maka dapat menyebabkan ibu kelelahan dan gangguan pada sirkulasi uteroplasenter sehingga janin di dalam rahim mengalami kekurangan oksigen, saat itu ketika bayi lahir akan mengalami asfiksia neonatorum ${ }^{13}$.

\section{METODE PENELITIAN}

Jenis penelitian ini menggunakan metode survey analitik dengan pendekatan Cross Sectional dimana variabel independent dan variabel dependent dikumpulkan dalam waktu yang bersamaan ${ }^{6}$.

Populasi penelitian ini ada semua bayi yang dirawat di rumah sakit umum daerah kota prabumulih yang berjumlah 1763 orang.

Metode sampel penelitian yang digunakan adalah Metode Random Sampling (suatu

teknik pengambilan sampel atau elemen secara acak dimana setiap elemen atau anggota populasi memiliki kesempatan yang sama untuk terpilih menjadi sampel) Dari populasi sebanyak 1763 orang dihitung rumus sebagai berikut:

Berdasarkan rumus diatas, maka didapatkan jumlah sampel sebesar 326 responden. Cara pengambilan sampek dilakukan dengan mengambil data sekunder, data sekunder yaitu data yang didapatkan daru suat lembaga instansi. Dalam penelitian ini data sekunder diperoleh dari data rekam medik rumah sakit umum daerah kota prabumulih. Wktu penelitian ini dan pengumpulan data dilakukan selama bulan januari-desember 2020 di Rumah Sakit Umum Kota Prabumulih. Analisis data yang digunaka

\section{HASIL PENENLITIAN}

Tabel 1. Distribusi Frekuensi Responden berdasarkan jumlah bayi yang dilahirkan di Rumah Sakit Umum Daerah Kota Prabumulih Tahun 2019

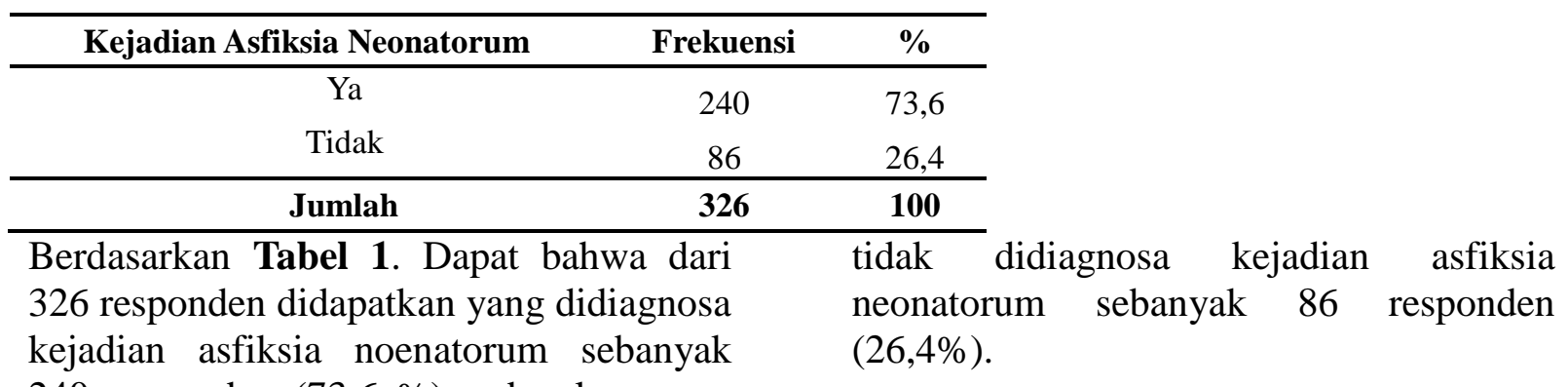

240 responden $(73,6 \%)$ sedangkan yang

Tabel 2 Distribusi Frekuensi Responden berdasarkan Paritas Ibu di Rumah Sakit Umum Daerah Kota Prabumulih Tahun 2019

\begin{tabular}{ccc}
\hline Paritas & Frekuensi & \% \\
\hline Resiko Tinggi & 168 & 51,5 \\
Resiko Rendah & 158 & 48,5 \\
\hline Jumlah & $\mathbf{3 2 6}$ & $\mathbf{1 0 0}$ \\
\hline
\end{tabular}


CENDEKIA MEDIKA

p-ISSN: 2503-1392

e-ISSN: 2620-5424

Berdasarkan Tabel 2 bahwa dari 326 responden didapatkan bahwa paritas ibu resiko tinggi sebanyak 168 responden
Volume 5 Nomor 2, September 2020

$(51,5 \%)$ sedangkan paritas ibu resiko rendah sebanyak 158 responden $(48,5 \%)$.

Tabel 3 Distribusi Frekuensi Responden berdasarkan Partus Lama di Rumah Sakit Umum Daerah Kota Prabumulih Tahun 2019

\begin{tabular}{ccc}
\hline Partus Lama & Frekuensi & \% \\
\hline Ya & 149 & 45,7 \\
Tidak & 177 & 54,3 \\
\hline Jumlah & $\mathbf{3 2 6}$ & $\mathbf{1 0 0}$ \\
\hline
\end{tabular}

Berdasarkan Tabel 3 bahwa dari 326 responden didapatkan bahwa ibu yang didagnosa partus lama sebanyak 149

responden $(45,7 \%)$ sedangkan ibu yang tidak didiagnosa partus lama sebanyak 177 responden $(54,3 \%)$

Tabel 4. Hubungan antara Paritas Ibu dengan Kejadian Asfiksia Neonatorum di Rumah Sakit Umum Daerah Kota Prabumulih Tahun 2019

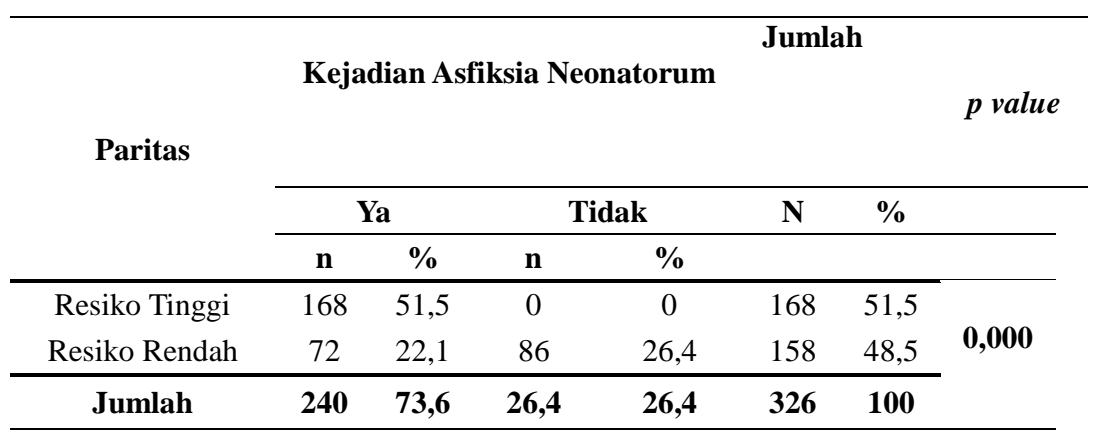

Berdasarkan hasil analisa bivariat dengan uji statistik mengunakan Chi-Square didapatkan hasil $p$ value $=0,000(p<$ $0,05)$ berarti hipotesis menyatakan bahwa ada hubungan yang bermakna antara paritas ibu dengan kejadian asfiksia neonatorum terbukti.

Tabel 4 Hubungan antara Partus Lama dengan Kejadian Asfiksia Neonatorum di Rumah Sakit Umum Daerah Kota Prabumulih Tahun 2019

\begin{tabular}{|c|c|c|c|c|c|c|c|}
\hline \multirow{3}{*}{$\begin{array}{l}\text { Partus } \\
\text { Lama }\end{array}$} & \multicolumn{4}{|c|}{$\begin{array}{c}\text { Kejadian Asfiksia } \\
\text { Neonatorum }\end{array}$} & \multicolumn{2}{|c|}{ Jumlah } & \multirow{3}{*}{$\begin{array}{c}p \\
\text { value }\end{array}$} \\
\hline & \multicolumn{2}{|c|}{ Ya } & \multicolumn{2}{|c|}{ Tidak } & \multirow[t]{2}{*}{$\mathbf{N}$} & \multirow[t]{2}{*}{$\%$} & \\
\hline & $\mathbf{n}$ & $\%$ & $\mathbf{n}$ & $\%$ & & & \\
\hline Ya & 149 & 45,7 & 0 & 0 & 149 & 45,7 & \multirow{3}{*}{$\mathbf{0 , 0 0 0}$} \\
\hline Tidak & 91 & 27,9 & 86 & 26,4 & 177 & 54,3 & \\
\hline Jumlah & 240 & 73,6 & 26,4 & 26,4 & 326 & 100 & \\
\hline
\end{tabular}


Berdasarkan hasil analisa bivariat dengan uji statistik mengunakan Chi-Square didapatkan hasil $p$ value $=0,000(p<0,05$ ) berarti hipotesis menyatakan bahwa ada hubungan yang bermakna antara partus lama dengan kejadian asfiksia neonatorum terbukti.

\section{PEMBAHASAN}

Berdasarkan distribusi paritas sebagian besar ibu yang melahirkan anak dengan jumlah $\leq 3$. Paritas adalah jumlah persalinan yang telah dialkukan ibu. Paritas 2-3 merupakan paritas paling aman ditinjau dari sudut kematian maternal. Paritas 1 dan paritas lebih dari 3 mempunyai angka kematian maternal yang disebabkan perdarahan pasca persalinan lebih tinggi. Paritas yang rendah (paritas satu), ketidaksiapan ibu dalam menghadapi persalinan yang pertama merupakan faktor penyebab ketidakmampuan ibu hamil dalam menangani komplikasi yang terjadi dalam kehamilan, persalinan dan nifas ${ }^{3}$.

Paritas satu berisiko karena ibu belum siap secara medis (organ reproduksi) maupun secara mental. Keadaan tersebut memberikan predisposisi untuk terjadi perdarahn, placenta previa, rupture uteri, solutiom placenta yang dapat berakhir dengan assiksia pada bayi baru lahir ${ }^{8}$.

Hal ini sejalan dengan Hasil penelitian ysng dilakukan oleh Gerungan Caroline J, dkk, di RSUP Prof. Dr. R.D Kandou Manado, menunjukkan pada paritas mempunyai nilai $p$ value $0,036(\mathrm{p}<0,05)$ yaitu ada hubungan antara paritas terhadap asfiksian neonatorum.

Berdasarkan hasil analisis bivariat didapatkan hasil chi-square yang dilakukan koreksi didapatkan p-value sebesar $0,000 \quad(<0,05)$. Yang berarti menunjukkan bahwa ada hubungan antara partus lama dengan kejadian asfiksia neonatorum. Partus lama yaitu persalinan berlangsung lebih dari 24 jam pada primi, dan lebih dari 18 jam pada multi. Partus lama masih merupakan masalah di indonesia $^{12}$.

Partus lama menimbulkan efek berbahaya bagi ibu dan janin, beratnya cedera meningkat dengan semakin lamanya proses persalinan. Resiko tersebut naik dengan cepat setelah waktu 24 jam. Angka kelahiran dengan tindakan yang tinggi semakin memperburuk bahaya bagi ibu sedangkan bahaya bagi janin semakin lama persalinan semakin tinggi morbidtas dan mortalitas janin san semakin sering pula terjadi keadaan asfiksia neonatorum ${ }^{7}$.

Bahaya pada partus lama lebih besar lagi apabila kepala janin macet di perineum untuk waktu yang lama dan tengkorak kepala janin terus terbentuk pada panggul ibu. Pada partus lama kala II, bradikardia janin kadang terjadi ketika ibu menahan nafas dalam waktu lama, dan usaha mengejan ibu dapat meningkatkan tekanan terhadap kepala janin. Efek pada janin mengakibatkan oksigen dalam darah turun dan aliran dara ke plasenta menurun sehingga oksigen yang tersedia untuk janin menurun, pada akibatnya dapat menimbulkan hipoksia janin ${ }^{7}$.

Hal ini sejalan dengan penelitian yang dilakukan oleh Gilang, dkk, di RSUD Tugurejo Semarang, dengan hasil analisis bivariat didapat hasil Chi-square yang sudah dilakukan koreksi didapat $p$-value sebesar 0,035 $(<0.05)$, yang berarti menunjukkan bahwa ada hubungan antara partus lama dengan kejadian asfiksia neonatorum.

\section{KESIMPULAN}

Berdasarkan hasil penetian disimpulkan sebagai berikut: (1) Ada hubungan yang bermakna antara Paritas dengan Kejadian Asfiksia Neonatorum Pada Bayi Baru Lahir di Rumah Sakit Umum Daerah Kota 
Prabumulih Tahun 2019, dimana $p$-value $=$ $(0,000)<0,05$. (2) Ada hubungan yang bermakna antara Partus Lama dengan Kejadian Asfiksia Neonatorum Pada Bayi Baru Lahir di Rumah Sakit Umum Daerah Kota Prabumulih Tahun 2019, dimana $p$ value $=(0,000)<0,05$.

\section{SARAN}

Dapat lebih memberikan pelayanan kesehatan berdasarkan standar profesinya dalam melakukan pelayanan asuhan kebidanan secara komprehensif. Dan dapat meningkatkan kemampuan dan keterampilan sehingga penanganan pada bayi baru lahir dengan asfiksia secara adekuat.

\section{DAFTAR PUSTAKA}

1. Ayu Mustika handayani. 2018. http://google.co.id hubungan paritas dan partus lama dengan kejadian berat badan lahir rendah di akses tanggal 17 februari 2020. Pukul 11.00 WIB

2. Elvina.2016.http://google.co.id hubungan-paritas dan partus lamadengan-kejadian-berat-badan-lahirrendah di akses tanggal 17 Februari 2020 pukul 11.00 WIB

3. Hubungan antara faktor ibu dengan kejadian asfiksia neonatorum di RSU Pandan ArangKabupaten Boyolali.(2009)

[updatedhttp://www.skripsistikes.word press.com/200. ; diakses 10 Juni 2014]

4. Manuaba, 2012.Ilmu Kebidanan Penyakit Kandungan dan Pelayanan Keluarga Berencana. Jakarta: EGC

5. Mochtar, Rustam, Sinopsis Obstetri. Edisi 2. Jilid 1. Jakarta: Buku Kedokteran EGC. 1998.
6. Notoadmodjo. 2014. Metodelogi Penelitian Kesehatan. Jakarta:Renieka Cipta

7. Prawirohardjo, (2002). Buku Acuan Pelayanan Kesehatan Maternal dan Neonatal. Yayasan Bina Pustaka Sarwono Prawirohardjo. Jakarta

8. Purnamaningrum Y E. Penyakit Pada Neonatus, Bayi dan Balita. Yogyakarta: Fitramaya; (2010). Katriningsih.

9. Riskesdas.2015.http://google.co.id.angka-kematian-bayi-tahun-2015 diakses tanggal 2 Januari 2018 pukul $12.30 \mathrm{WIB}$

10. Rukiyah, dkk. 2012. Asuhan Bayi Baru Lahir. Jakarta : Trans Info Media

11. Sudarti, dkk. 2016.Asuhan Kebidanan Neonatus Reisko Tinggi dan Kegawatan. Yogyakarta : Nuha Medika

12. Sulistianingsih. Metodologi Penelitian Yogyakarta: Graha Ilmu; (2011)

13. Maharani S. 2014. Panduan Sehat dan Cerdas Menghadapi Kehamilan. Kata Hati: Yogyakarta. 